\title{
НАЛЕЖНА ОРГАНІЗАЦІЯ АТЕСТАЦІЇ ВИПУСКНИКІВ - ВАЖЛИВА СКЛАДОВА РЕАЛІЗАЦІЇ ЗАКОНУ УКРАЇНИ “ПРО ВИЩУ ОСВІТУ”
}

\author{
Ю. С. П’ятницький, І. Є. Булах, І. В. Мельник, М. Р. Мруга, М. О. Поліщук, \\ Л. П. Войтенко
}

Міністерство охорони здоров'я України, ДУ “Центральний методичний кабінет з вищої медичної освіти МОЗ України”, ДО “Центр тестування професійної компетентності фахівців з вищою освітою напрямів підготовки “Медицина” і “Фармація” при МОЗ України”

\section{THE PROPER ORGANIZATION OF CERTIFICATION OF GRADUATES AS AN IMPORTANT COMPONENT OF THE LAW OF UKRAINE “ON HIGHER EDUCATION”}

\section{Yu. S. Pyatnytskyi, I. Ye. Bulakh, I. V. Melnyk, M. R. Mruha, M. O. Polishchuk, L. P. Voytenko}

The Ministry of Healthcare of Ukraine

SI "Central methodical cabinet of higher medical education the Ministry of Health of Ukraine", SO "Center for testing professional competence of specialists with higher education training directions "Medicine" and "Pharmacy" Ministry of Health of Ukraine"

\footnotetext{
У статті наведено принципи та особливості проведення атестації випускників українських вищих медичних та фармацевтичних навчальних закладів у 2016 р.

The article presents the principles and features of certification of graduates of Ukrainian medical and pharmaceutical universities in 2016.
}

Вступ. Відповідно до статті 13, пункту 2, підпункту 5 Закону України від 1 липня 2014 р. № 1556-VII “Про вищу освіту” (далі - Закон України “Про вищу освіту”) державні органи, до сфери управління яких належать вищі навчальні заклади, аналізують якість освітньої діяльності вищих навчальних закладів, що належать до сфери їх управління [1]. Саме тому Міністерство охорони здоров’я України (далі - МОЗ України), ураховуючи пункт 4 Положення про Міністерство охорони здоров’я України, затвердженого Указом Президента України від 13 квітня 2011 р. № 467, “...відповідно до покладених на нього завдань аналізує якість освітньої діяльності вищих навчальних закладів, що належать до сфери управління МОЗ України”.

(c) Ю. С. П’ятницький, І. Є. Булах, І. В. Мельник та ін.
3 метою удосконалення методичного забезпечення проведення атестації випускників у вищих навчальних закладах, підпорядкованих МO3 України, з листом МОЗ України від 30.12.2015 р. № 23-01-9/671 до вищих навчальних закладів MO3 України надіслано для врахування в роботі оновлену відповідно до статті 6 Закону України “Про вищу освіту” примірну форму Звіту голови екзаменаційної комісії (далі - звіт), розроблену на підставі примірної форми Звіту голови Державної екзаменаційної комісії, затвердженої МОЗ України 21.05.2014 р. (лист МОЗ України від 21.05.2014 р. № 08.01-47/14038) [4, 6].

Основна частина. Примірна форма звіту сформована з урахуванням пропозицій моніторингових груп, які вивчали організацію навчальнометодичного забезпечення навчального процесу у вищих медичних (фармацевтичному) навчальних 
закладах (далі - ВМ(Ф)НЗу, 2012 - 2014 рр. на виконання наказу МО3 України від 24.10.2012 р. № 834 “Про навчально-методичну діяльність вищих медичних та фармацевтичних навчальних закладів I-IV рівнів акредитації”; підсумків обговорення питань удосконалення атестації випускників на семінарах, проведених на виконання наказу МОЗ України від 28.10.2013 р. № 232-Адм. “Про проведення короткотривалих семінарів-тренінгів для начальників навчальних відділів та семінару для фахівців, відповідальних за впровадження системи менеджменту якості (згідно з вимогами ДСТУ ISO 9001 : 2009) у вищих медичних (фармацевтичному) навчальних закладах" [2, 3, 5].

Слід нагадати, що з метою удосконалення підготовки студентів старших курсів до випускних екзаменів та покращення організації і проведення атестації випускників за підсумками напрацювань учасників семінарів-тренінгів було підготовлено та впроваджено у роботу ВМ(Ф)НЗ ряд документів, зокрема:

- Методичні рекомендації з підготовки до ліцензійних інтегрованих іспитів “Крок 1” і “Крок 2” як галузевого моніторингу якості вищої медичної освіти відповідно до Європейських вимог (для студентів та викладачів), підготовлені з урахуванням Порядку проведення ліцензійних інтегрованих іспитів, погодженого з МО3 України 29.04.2013 р. Методичні рекомендації надіслані до ВМ(Ф)НЗ з листом МОЗ України від 06.11.2013 р. № 23-019/137;

- Інструкцію щодо оцінювання навчальної діяльності студентів в умовах впровадження Європейської кредитно-трансферної системи організації навчального процесу (затверджена заступником міністра охорони здоров'я та надіслана для впровадження з листом МОЗ України від 15.04.2014 р. № 08.01-47/10395);

- Методику проведення підсумкового семестрового контролю за результатами складання модулів 3 дисциплін, які $€$ складовою державної атестації випускників (листи МО3 України від 06.11.2013 р. № 23-01-9/138 та № 23-01-9/139).

На виконання доручень МОН України (лист МОН України керівникам вищих навчальних закладів від 20.01.2015 р. № 1/919 “Щодо організації атестації здобувачів вищої освіти та організації освітнього процесу”) та ДУ “Центральний методичний кабінет з вищої медичної освіти МОЗ України” (лист до ректорів вищих навчальних закладів МОЗ України від 30.01.2015 р. № 23-01-9/40) необхідно було розробити (оновити) положення про атестацію випускників та положення про екзаменаційну комісію. Підсумки моніторингу навчально-методичної діяльності вищих медичних та фармацевтичних навчальних закладів і закладів післядипломної освіти, підпорядкованих МОЗ України, проведеного на виконання наказу МОЗ України від 24.10.2012 р. № 834 “Про навчально-методичну діяльність вищих медичних та фармацевтичних навчальних закладів I-IV рівнів акредитації” і відповідно до Графіка моніторингу навчально-методичної діяльності вищих медичних та фармацевтичних навчальних закладів та закладів післядипломної освіти, підпорядкованих МОЗ України, на 2016 р., затвердженого міністром охорони здоров’я О. Квіташвілі 14.01.2016 р., свідчать про те, що такі положення у ВМ(Ф)НЗ були розроблені.

Якісне заповнення інформації у таблиці 2.1 Звіту дає змогу оцінити ефективність заходів навчального закладу із збереженням контингенту студентів, основні причини відрахування студентів, відсоток студентів, які не склали інтегровані іспити “Крок 1 ” i “Крок 2”.

Слід зробити наголос на тому, що у розділі 5 Звіту “Пропозиції голови екзаменаційної комісії щодо поліпшення якості професійної підготовки випускників” голова екзаменаційної комісії має зазначити:

- загальну характеристику підготовки фахівців 3 напряму підготовки (спеціальності) і характеристику знань, умінь та компетенцій випускників; якість виконання проектів (робіт), актуальність їхньої тематики та відповідність сучасному стану науки, техніки і виробництва (для галузі знань “Фармація”);

- недоліки, допущені у підготовці фахівців, зауваження щодо забезпечення організації атестації випускників;

- пропозиції голови екзаменаційної комісії щодо: поліпшення якості підготовки фахівців; усунення недоліків в організації проведення атестації випускників і захисту випускних проектів (робіт); можливості публікації основних положень проектів (робіт), їх використання у навчальному процесі на підприємствах, в установах та організаціях; надання випускникам рекомендації щодо вступу до аспірантури. 
Разом $з$ тим, як свідчать матеріали аналізу звітів голів ДЕК у 2014 та 2015 рр., часто цей розділ описується формально [7].

У багатьох звітах з року в рік повторюються одні і ті ж зауваження і пропозиції, що може свідчити про недостатній рівень роботи з ліквідування раніше виявлених недоліків у навчальних закладах або про формальний підхід з боку голови екзаменаційної комісії до формування зауважень та пропозицій.

Як уже зазначалось під час узагальнення підсумків атестації у минулому році, у переліку нормативних документів, на підставі яких проводилась атестація випускників, у багатьох звітах містяться посилання на нормативні документи, які вже втратили чинність, неправильно вказано назви наказів та їх реквізити.

Узагальнення підсумків результатів складання ліцензійних інтегрованих іспитів “Крок 2”, що $€$ складовою частиною атестації випускників, у минулому році свідчить, що порівняно з результатами складання цих іспитів у попередніх роках спостерігається покращення результатів. Зокрема, кількість студентів, які не склали ліцензійний іспит “Крок 2”, у 2013 р. становила 243 (2,9 \%) студентів, у 2014 р. - 175 (2,1 \%) студентів, у 2015 р. - 116 (1,4 \%) студентів.

Результати складання ліцензійних іспитів “Крок 2” студентами-громадянами іноземних держав у 2015 р. знаходяться у таких самих межах, як у 2013 р. Зокрема, кількість студентів-громадян іноземних держав, які не пройшли атестацію, у 2013 р. становила 229 (8,3 \%) студентів, у 2015 р. - 243 (9,0 \%) студентів.

Відповідно до статті 6 розділу II Закону України “Про вищу освіту” атестація осіб, які здобувають ступінь молодшого бакалавра, бакалавра чи магістра, здійснюється екзаменаційною комісією, до складу якої можуть включатися представники роботодавців та їх об’ єднань, відповідно до положення про екзаменаційну комісію, затвердженого вченою радою вищого навчального закладу.

Для проведення атестації випускників у 2016 р. наказом МО3 України від 11.01.2016 р. № 3 затверджено персональний склад голів екзаменаційних комісій у 2016 р., який сформовано, переважно, 3 урахуванням пропозицій ВМ(Ф)НЗ, підпорядкованих MO3 України. Перш за все, до складу голів екзаменаційної комісії були включені представники інших вищих навчальних закладів MO3 та МOH
України, представники роботодавців. Включення до складу голів екзаменаційних комісій фахівців закладів післядипломної освіти сприятиме удосконаленню послідовної підготовки випускників вищих медичних (фармацевтичного) навчальних закладів в інтернатурі.

Як зазначено у пункті 5 таблиці 1.3 Звіту “Загальна інформація про склад екзаменаційної комісії, екзаменаторів тощо”, до проведення атестації випускників доцільно залучати наукових співробітників, фахівців з відповідних видів виробничої діяльності, представників галузевих об'єднань роботодавців, разом 3 тим, у якості екзаменаторів мають бути доктори та кандидати наук.

При проведенні атестації випускників у 2016 р. необхідно врахувати узагальнені підсумки атестації випускників ВМ(Ф)НЗ у 2015 р., надіслані з листом МОЗ України від 18.02.2016 р. № 08.0147/3951. Зокрема наявність у навчальному закладі системної роботи з усунення недоліків в організації підсумкової атестації, проведенні деканатами та випускаючими кафедрами до атестації методичної, навчальної та виховної роботи, підготовці викладацьких кадрів вченої кваліфікації для забезпечення викладання дистанційно на старших курсах.

Відповідно до статті 16 розділу V Закону України “Про вищу освіту”, система забезпечення якості вищої освіти в Україні складається із:

1) системи забезпечення вищими навчальними закладами якості освітньої діяльності та якості вищої освіти (система внутрішнього забезпечення якості);

2) системи зовнішнього забезпечення якості освітньої діяльності вищих навчальних закладів та якості вищої освіти;

3) системи забезпечення якості Національного агентства із забезпечення якості вищої освіти i незалежних установ оцінювання та забезпечення якості вищої освіти.

Висновки: 1. Належне проведення атестації випускників ВМ(Ф)НЗ є свідченням наявності сформованої системи забезпечення вищими навчальними закладами якості освітньої діяльності та якості вищої освіти, а проведення МОЗ України аналізу підсумків атестації є складовою системи зовнішнього забезпечення якості освітньої діяльності вищих навчальних закладів та якості вищої освіти.

2. Урахування зазначеного сприятиме удосконаленню організації атестації випускників ВМ(Ф)НЗ у 2016 p. 


\section{Список літератури}

1. Про вищу освіту : Закон України від 01.07.2014 р. № 1556-VII.

2. Інструкція щодо оцінювання навчальної діяльності студентів в умовах впровадження Європейської кредитно-трансферної системи організації навчального процесу : лист МОЗ України від 15.04.2014 р. № 08.01-47/10395 до ректорів вищих медичних (фармацевтичного) навчальних закладів IV рівня акредитації.

3. Методичні рекомендації з підготовки до ліцензійних інтегрованих іспитів “Крок 1” і “Крок 2” як галузевого моніторингу якості вищої медичної освіти відповідно до Європейських вимог (для студентів та викладачів) : лист МО3 України від 06.11.2013 р. № 23-01-9/137.

4. Оновлена примірна форма звіту голови екзаменаційної комісії : лист МОЗ України від 30.12.2015 р. № 2301-9/671 до ректорів вищих навчальних закладів.
5. Особливості атестації випускників вищих медичних (фармацевтичного) навчальних закладів у 2015 році / О. П. Волосовець, Ю. С. П’ятницький, Л. В. Соколова [та ін.] // Реалізація Закону України “Про вищу освіту” у вищій медичній та фармацевтичній освіті України : матеріали Всеукр. навч.-наук. конф. з міжнар. участю, присвяченої пам'яті ректора чл.-кор. НАМН України, проф. Леоніда Якимовича Ковальчука. - Тернопіль : ТДМУ, 2015. - С. 19-20.

6. Примірна форма звіту голови державної екзаменаційної комісії : лист МОЗ України від 21.05.2014 р. № 08.01-47/14038.

7. Узагальнені підсумки атестації випускників вищих медичних (фармацевтичного) навчальних закладів МО3 України у 2015 році : лист МОЗ України від 18.02.2016 р. № 08.01-47/3951. 